\title{
When All Roads Lead to Rome: The Catholic Hospital Dilemma Impacts Entire US Healthcare System
}

\author{
Mary Ann Keogh Hoss ${ }^{1}$, Kevin S. Decker ${ }^{2}$ \\ ${ }^{1}$ Department of Urban Planning Health and Public Administration, Eastern Washington University, \\ Spokane, USA \\ ${ }^{2}$ College of Arts, Letters \& Education, Eastern Washington University, Spokane, USA \\ Email: mhoss@ewu.edu, kdecker@ewu.edu
}

Received September $7^{\text {th }}, 2013$; revised October $7^{\text {th }}, 2013$; accepted October $15^{\text {th }}, 2013$

\begin{abstract}
Copyright (C) 2013 Mary Ann Keogh Hoss, Kevin S. Decker. This is an open access article distributed under the Creative Commons Attribution License, which permits unrestricted use, distribution, and reproduction in any medium, provided the original work is properly cited.
\end{abstract}

\begin{abstract}
With the stripping of 2 Catholic Hospitals of their status as Catholic in 2010, much information has come forward on the 72 Ethical and Religious Directives (ERDs) of the Catholic Hospital Association of the United States (CHA). With this, the authority of the bishops of the Catholic Church in relationship to delivery of health care has been called into question. The decision of the bishop in Phoenix has raised clinical, ethical and operational concerns which are explored. CHA claims that 1 in every 6 patients in the US is in a Catholic Hospital. The questions related to the public on the impact of the ERDs for their healthcare are staggering. Is one's healthcare in the hands of a bishop? Should some ethical dilemma occur? These questions are explored.
\end{abstract}

Keywords: US Healthcare System; Catholic; Ethical and Religious Directives; Bishops

\section{When All Roads Lead to Rome}

The Catholic Hospital Association of the United States (CHA, 2011) claims one in six patients in the United States is cared for in a Catholic Hospital. The December 2010 decision of Bishop Thomas J Olmsted of Phoenix, Arizona to strip St. Joesph's Hospital of its Catholic status creates additional challenges for Catholic Hospital administrators in healthcare today. This is the second Catholic hospital to lose Catholic status in 2010. St. Charles Medical Center in Baker, Oregon lost its status in February (Mann, 2011).

\section{Phoenix Action}

The Phoenix action arose over the following incident. In 2009, a woman 11 weeks pregnant presented at the hospital with deteriorating pulmonary hypertension hat had begun to seriously threaten her life. Doctors informed her that risk of death was close to $100 \%$ (Tenety, 2011). An abortion was performed to save the live that could be saved. Bishop Olmsted stated,"...the baby was healthy and there were no problems with the pregnancy; rather, the mother had a disease that needed to be treated. But instead of treating the disease, St. Joseph's medical staff and ethics committee decided that the healthy, 11 week old baby should be killed. This is contrary to the teaching of the church" (Tenety, 2011: p. B02). It should be noted that Bishop Olmsted's bio does not include any clinical training. It does include numerous years of service in Rome (Roman Catholic Diocese of Phoenix, 2011).

\section{Catholic Hospitals}

According to the Catholic Hospital Association, there are more than 600 Catholic hospitals in the United States with as many as 45 of those being the sole providers of hospital care in their communities. The total number of community hospitals in the US according to the American Hospital Association is 5008 (AHA, 2010). Of those 2918 are nongovernmental not for profit hospitals. The Catholic affiliated hospitals make up roughly one fifth of that number. The parent company for St. Joseph's Hospital is Catholic Health Care West, the eighth largest healthcare company in the US (Mann, 2011) The CHA (2011) fact sheet based on AHA 2009 data shows $16.7 \%$ of care for Medicare patients is received in Catholic Hospitals as well as $13.5 \%$ of care for Medicaid patients. Catholic Hospital administrators struggle with complex issues; among those challenges are community trust, governance, damages in human capital, finance capital and quality of care. But the overriding issue of community trust presents as the most serious of these challenges especially as this decision has been communicated throughout the US. In a world of "perception is reality", the message take away from this incident is not positive to say the least. This leaves a lingering after taste for women and indeed any community member seeking care and treatment in Catholic hospitals who may fear for their lives as this denunciation suggests, follow doctrine not clinical indicators in matters of live and death.

The rest of the nation must closely watch what is happening with the Catholic Healthcare systems. A much larger picture emerges with this type of news that travels the nation. While bishops have long been silent most likely because of the numerous scandals plaguing the Church, they now have an avenue for visibly and vocally asserting their authority. This quote from Bishop Olmsted says it all "It is my duty as the chief 
shepherd in the diocese to interpret where the actions at St. Joseph's meet the criteria of fulfilling the parameters of the moral law as seen in the Ethical and Religious Directives (ERD)" (Hendershott, 2010). How safe does the American public feel in having a bishop of the Catholic Church with no known clinical background deciding their fate while in a Catholic hospital? The Catholic Hospital United States Conference of Catholic Bishops Association (CHA) with the United States Conference of Catholic Bishops (USCCB) announced that they have agreed on the following after much discussion:

... Archbishop Dolan of New York goes on to say "any medical case, and especially one with unique complications, certainly requires appropriate consultation with the medical professionals and ethical experts with specialization in the teaching of the church. Still, as you have reasserted, it is the diocesan bishop's authentic interpretation of the ERD's that must govern their implementation. Where conflict arises, it is again the bishop who provides the authoritative resolution based on his teaching office. Once such a resolution of doubt has been given, it is no longer a question of competing moral theories or the offering of various ethical interpretations or opinions of the medical data that can still be legitimately espoused and followed. The matter has now reached the level of an authoritative resolution” (Zenit News Agency, 2011: p. 1). The implications for this are staggering.

\section{The Ethical and Religious Directives for the Catholic Health Care Services}

In November 2009, the USCCB issued the $5^{\text {th }}$ edition of the ERD. These are 72 directives which direct Catholic Health Care Services. The updated ERD has 2 purposes. These are "to reaffirm the ethical standards of behavior in health care that flow from the church's teaching about the dignity of the human person and to provide authoritative guidance on certain moral issues that face Catholic health care today” (USCCB, 2009: p. 4). These directives are guided by 5 principles for the Church's healing ministries. As stated by Archbishop Dolan, the authority of the bishop supersedes the rights of patients and individual doctors. What does the stripping of Catholic status really mean? A hospital may no longer refer to itself as Catholic, mass can't be said and the diocese where it resides will not support it (Gerardi, 2010). It is unclear what types of support that includes and whether or not communion may be received by patients.

\section{US Healthcare Crisis}

With a US healthcare system in crisis, having one fifth of the system engaged in this type of controversy is onerous. The American Hospital Association report on the economic recession shows that $74 \%$ of hospitals reported reduced operating margins. Half of hospitals are reporting decreased non-operating income. $89 \%$ of hospitals report back that they have not added back staff or increased staff hours and 98\% have not restored services or programs previously cut (AHA, 2010). Medicare and Medicaid fact sheet show that" payments continue to fall below costs and the shortfall is growing” (AHA, 2010: p. 2).

Is there trust in the bishop's of the United States to fairly and justly deal with the very serious issues pertaining to healthcare in each and every community where a Catholic hospital resides? Based on the most recent scandals is there faith in their judgment based on the nation's view of how the sex abuse issues were handled? In the large hospital systems residing in multiple states where the consistency of thought may not go across bishops, who decides and how is that transmitted throughout the system?

Where do these issues become the issues for the nation facing a crisis in healthcare? Catholic healthcare administrators and leaders should now be required to respond to the following. What is the average consumer to do? If there is only one provider of hospital care in a geographic area what does a consumer do? Do the ERDs impact all healthcare arenas where Catholic services are provided-subacute care, skilled nursing, home health, adult day care/assisted living/residential care and hospice? Are all potential clients notified in writing of what constitutes the ERDs and the possible impact on them? Are physicians with admitting privileges aware of the 72 directives and their impact on care. Are providers educated on the 72 ERDs? Do patients and providers understand what rights regarding privacy and confidentiality may be violated when a bishop becomes involved in individual healthcare decision making? Do all providers and their patients understand the implications of this and are they advised in writing?

As a nation, healthcare is taking more and more of a toll on the US public. Health care systems are trying desperately to meet the demands of a nation unclear on how to proceed with the delivery of services. The Phoenix decision is evidence that patient rights and clinical judgment appear to be secondary to the authority of a bishop. Would the government refuse to pay for care based on a decision made? Who is liable? Who pays? All of these issues could be pushed based on the fact that serious dilemmas will arise as technology and constant change in healthcare continue to occur. Is the patient at risk and does he or she know it based on Catholic doctrine?

\section{Biomedica Ethics Involved}

Some of the reportage of the case of Bishop Olmsted and St. Joseph's Hospital has mischaracterized the issues at stake by ignoring the fact that the debate over the correctness of care at St. Joseph's (or, indeed, any hospital or care facility) should be evaluated in terms of plural cultures within a democratic setting that legally and morally values an individual's autonomous decisions. One should not be surprised, for example, that Benjamin Mann, staff writer of the Catholic News Agency, toes the Olmstedian party line when reporting on the controversy. More worrisome, however, is his citing of John Brehany, executive director of the Catholic Medical Association, who puts the onus for the excommunication of St. Joseph's on the hospital itself. "We don't want you in our life", was the message that St. Joseph's sent to the Church by their actions, Brehany claimed. Brehany further went on to compare "the situation between the bishop and St. Joseph's to a child who decides to break off contact with his parents" (Mann, 2011). Taken at face value, this seems to derogate the clinical and ethical claims of the St. Joseph's staff, supported by the arguments of theologians and bioethicsts, to the whining of teenagers. Is this a morally acceptable way to characterize one's opponents in an argument?

\section{Framing the Issue}

In a more insidious example of framing in the issue, Anne Hendershott (2010), uncharitably portrays the claims of Lloyd Dean, president of Catholic Healthcare West, the hospital's 
parent company. Hendershott parses Dean’s opposition to Olmsted's decision in this way: “... Mr. Dean appeared to suggest that the teaching authority of the Phoenix Bishop was just one more 'opinion' on a 'complex matter'." In fact, Dean said that "this is a complex matter on which the best minds disagree," and cited the expert opinion of M. Therese Lysaught, Associate Professor of Theology at Marquette University, whose training includes an MA in Theology from Notre Dame and a PhD in Religion and Theological Ethics from Duke University. But Hendershott has clearly made her mind up in advance about the results of a disagreement between, say, Olmsted and Lysaught when she writes: "Many theologians ... write that theologians comprise 'an alternative magisterium' to the teaching authority of the bishops. And in cases like the one at St. Joseph's, the alternative magisterium often trumps the true Magisterium of the church." She apparently ignores that fact that many "alternative" church fathers, including Saint Clement, Origen, Tertullian, and Saint Jerome, never held any formal position within the church hierarchy. And as guilty as Dean was in omitting the considered views of ethicists who disagreed with him in his communications with Olmsted, Hendershott herself is as guilty in failing to consider the Bishop's complete lack of clinical competence.

To cast the issue, as Hender shott and many Catholic commentators do, as a failure to heed prescriptive authorities is to cede the controversy to Bishop Olmsted without debate and, further, to ignore the opportunity for moral deliberation and transformation that might ensue. From the perspective of medical care within a pluralistic democracy such as the United States, there are at least two key issues at stake in the St. Joseph's Hospital case: clinical competence and conscience. As can be shown, these are not necessarily at odds with each other, either in this case or in such cases in general.

\section{Patient's Right}

There is at least a prima facie plausibility to the individual's claim that, in a clinical or pharmaceutical setting, their conscience requires them to "opt out" of a professionally required duty. However, it is a mistake to think that conscience should automatically trump such duties, since in any scenario where treatment or services might be denied, one also must weight in the pre-commitment of the medical professional to the normal performance of their duties, as well as the claim of the patient to their well-being. Claims of conscience, at least in American legislative history (the Church Amendment, 1973; the Hyde Amendment, 1976; the Weldon Amendment, 2004) are based on two principles: 1) the right of an individual to secure his or her own moral integrity, and 2) the incorrigibility of the dictates of conscience. While individuals do have the right to their moral integrity, this is not an absolute right, especially in cases where it can be shown that an autonomous individual accepted professional responsibilities that they were aware might impinge on their sense of moral integrity. Especially in such cases of conscience, the strict burden of proof should be placed on the individual to indicate the precise reasons for their opting out. Further, because of a patient's right to receive therapeutic treatments or critical care that are not forbidden by law, conscientious dissenters and/or their institutions should be obligated to inform a patient where and how they can receive the treatment or services requested; in other words, the right to conscientious opting out does not extend to a right to absolutely deny a patient services and information.

It is also arguable that the dictates of conscience are incorrigible; while an individual may have a strong moral intuition in a given situation, it is not always true that their conscience is speaking. Particularly in cases where an individual's moral intuitions are inconsistent with each other, we have good reason to believe that at least some of their intuitions are actually giving voice to habit, woolly thinking, parental or peer influence, or religious training. It may also be the case that while I do not doubt that my conscience has "spoken”, I may be wrong about the fact that such a moral intuition applies in this particular case, or how it applies in this case. This is another reason why the presence of biomedical ethicists is still significant in clinical care settings, and a reminder of the danger of having one individual make decisions that directly and irreversibly impact, in a negative fashion, the fundamental health and well-being of hundreds or thousands of others.

\section{Claims of Conscience}

Claims of conscience in the Catholic healthcare setting are most likely to be encountered by providers demurring from providing services that violate principles the ERD That is, Catholic health professionals may make negative conscience claims that they should not be compelled to provide services that impinge on their conscientious moral intuitions. However, as Mark Wicclair points out, there are also positive conscience claims that can be made to justify "provid[ing] professionally permitted medical goods or services (e.g., medications and procedures) when do so is prohibited by law, institutional rules, employer policies, and so forth” (Wicclair, 2009: p. 15).

The termination of the pregnancy of the 11-week pregnant woman at St. Joseph's that incited Olmsted is best justified as demanded as a positive claim of conscience. Sister McBride's decision in the case was made more difficult, of course, by the Church's teaching that the fetus is a person. But at a non-viable age of 11 weeks old, the fetus could not have been classified as a distinct patient, deserving of patient rights and treatment considerations, at least in non-Catholic hospitals. In these settings, the standard ethical practice is that "beneficence-based obligations to the fetal patient should be negotiated in the context of the beneficence and autonomy of the mother" (Springer, 2011).

In following the ERD, McBride and the staff at St. Joseph's attempted to save the only life that was possible to save. The decision hinged on the mother's diagnosis of pulmonary hypertension as a near-certain risk of death; The patient realized this in her decision to abort the pregnancy. What Bishop Olmsted failed to comprehend, but what St. Joseph's apparently did, is that a mother need not suffer from a "grave illness" in order that both the lives of her and her baby are at risk. The doctrine of double effect (DDE) clearly allows McBride, in this case, to make a decision in which the intention is to save the life of the mother even though she also knows that the fetus's life will be ended; the alternative would be that both would die. Whether or not the reasoning of the DDE is sound, McBride's case should be one of a positive claim to conscience. What we then have is the unusual case of assessing the justifiability of this claim not from within the structure of a religious institution, but against it.

Which issue should one weight more heavily in this case, Bishop Olmsted's lack of clinical competence or the claims of St. Joseph's clinical professionals to permissibly dissent, on the 
basis of conscience, from Olmsted's interpretation of Catholic doctrine? Despite Bishop Olmsted's diverse background in Catholic affairs, including his current service as member of the Catholic Association of Latino Leaders and the USCCB Missions Committee, as well as various positions dealing in Personal and Priestly Formation and a stint on the Board of Directors for the Catholic Legal Immigration Network, appears to have no formal clinical or documented biomedical ethical training. With regard to the last of these, it is not enough to say that Olmsted encountered Catholic bioethics in seminary work in philosophy and his doctoral studies at Rome's Gregorian University.

The pluralistic nature of the field of American bioethics requires that an expert in this field have documented evidence of having engaged with moral theories, including not only secular views such as deontology and utilitarianism, but also nonCatholic religious theories; it further requires lay academic or advisory committee engagement with argumentative opponents from a diverse range of ethical perspectives.

\section{Summary}

Bishop Olmsted's lack of experience in these regards contrasts distinctly with that of Sister Margaret McBride and Lloyd Dean of Catholic Healthcare West. Olmsted's repeated claims that his retributive acts against St. Joseph's are sanctioned by his role as "shepherd" and "teacher" seem oxymoronic. His decision to declare that St. Joseph's is no longer "Catholic" is one that will undoubtedly (and unjustifiably) hurt the hospital's reputation with many of its more doctrinaire clientele. Faith and moral claims of conscience have been, and likely will always be, central to the religious life. If Catholic identity is partly based on the ability of being faithful to invoke their conscience against a wider, secular society's standards, isn't there hypocrisy to denying individuals the right of reasoned, conscientious dissent within the church (O’Rourke, 2001)? Particularly when, as in this case, the central Catholic value of life was maximized in a case in which the only other alternative was two deaths. Adherents of freedom of conscience supported (and perhaps challenged) by a robust debate on ethical and clinical issues underpinning hard cases should stand with Sister Margaret McBride and the rest of the hospital administrators and staff.
They-and not Bishop Olmsted-represent the synthesis of clinical competence and ethical sensitivity required to further the mission of genuinely Christian hospitals in a pluralistic democracy.

\section{REFERENCES}

American Hospital Association (2010a). Hospitals continue to feel lingering effects of the economic recession. http://www.aha.org/aha/research-and-trends/index.html

American Hospital Association (2010b). Underpayment by Medicare and Medicaid fact sheet. http://www.aha.org/aha/content/2010/pdf/10medunderpayment.pdf

Catholic Health Association of the United States (2011). Catholic health care in the United States. January 2011.

Gerardi, J. (2010). Phoenix's Augean stables. The Daily Caller. http://dailycaller.com/2010/12/30/phoenixs-augean-stables/print/

Hendershott, A. (2010). Catholic hospitals vs. the bishops. Wall Street Journal.

http://online.wsj.com/article/SB100014240529702037310045760464 43911321586.html

Mann, B. (2011). Phoenix hospital's break with bishop a troubling sign, health care experts say. Catholic News Agency. http://www.catholicnewsagency.com/news/phoenix-hospitals-breakwith-bishop-a-troubling-sign-health-care-experts-say/

O’Rourke, K. (2001). Catholic hospitals and catholic identity. Christian Bioethics, 7, 15-28. http://dx.doi.org/10.1076/chbi.7.1.15.3762

Roman Catholic Diocese of Phoenix (2011). Highlights in the life of Bishop Olmstead. http://www.diocesephoenix.org/bishop/olmstedLifeHighlights.htm

Springer, S. (2011). Fetus as Patient. eMedicine. http://emedicine.medscape.com/article/936318-overview

Tenety, E. (2011). Bishop says Ariz. Hospital is no longer "Catholic" after abortion to save mother's life. The Washington Post. http://onfaith.washingtonpost.com/onfaith/undergod/2010/12/st_jose phs_hospital_no_longer_catholic_after_abortion_to_save_mothers_li fe.html

United States Conference of Catholic Bishops (2009). Ethical and religious directives for Catholic health care services (5th ed.). Washington, DC: USCCB.

Wicclair, M. (2009). Negative and positive claims of conscience. Cambridge Quarterly of Healthcare Ethics, 18, 14-22. http://dx.doi.org/10.1017/S096318010809004X

Zenit News Agency (2011). Catholic Hospital Association reaches agreement with Bishops. Zenit News Agency. http://www.catholic.org/national_story.php?id=40189\&wf=rsscol 